\title{
Cost analysis of type 2 diabetes mellitus treatment in economically developed countries
}

\begin{abstract}
Introduction: There is a growing need to evaluate the factors contributing to the increase in health expenditures, as well as the cost of medicines used in the treatment of T2DM in the economically developed countries.

Areas covered: A systematic searching of studies describing the direct cost of T2DM and medicine cost of treating T2DM. The quality of the studies found eligible for this study were assessed using a methodological quality appraisal tool. Nine studies were included in this review. All the included studies had data on direct cost and antidiabetic medicine cost of health care. Mean annual direct cost per person/year ranged between US\$220 and US\$7,600. The two components with the greatest impact on direct cost was found to be medicines and hospitalization. The mean annual medicines cost per person/year was found to range between US\$140 and US\$2,990.
\end{abstract}

Expert commentary: There is an increased expenditure on treatment of T2DM. However, it is still not clear how the increased use of antidiabetic medicines is reflected in the overall expenditures. Further, we suggest a more comprehensive understanding of prescription patterns as older drug are more expensive than the newer drugs hence they are still under patent.

\section{Introduction}

Type 2 diabetes mellitus (T2DM) is a metabolic disorder caused by increased blood glucose levels. Previously this disease was known as non-insulin-dependent diabetes and was most often diagnosed in people over 40 years. However, T2DM has now become a more common disease and an increasing number of children and younger adolescents present with diabetes (Diabetes.co.uk; Hsia et al., 2009). According to the international diabetes federation, one in eleven adults has diabetes. This equals 424.9 million people at a global level. Further, 210 million adults with diabetes are estimated to be unaware of their disease (IDF, 2018). T2DM is considered a global health problem and prevalence has been found to be rising in recent years and expected to keep growing. This phenomenon has been found to evolve in association with 
cultural changes, an aging population, increased consumption of unhealthy foods and reduced physical activity (IDF, 2018; Saito et al., 2011).

Global health expenditure in 2006 for people aged 20-79 was found to be \$232 in 2017 it had increased to $\$ 727$, and this number is expected to further increase to $\$ 776$ by 2045 . The projection for 2045 may be underestimated as it includes the mean expenditure per person and diabetes prevalence rate to remain constant (IDF, 2018). Despite the fact that most people with diabetes live in low- and middle-income countries, studies show that $80 \%$ of all global health expenditure is projected to be in the world's economically richest countries (Zhang et al., 2009). Hence, there is a need to create awareness about generic prescribing, reimbursement of medicines and implementation of international guidelines into current practices (Babar et al., 2011; IDF, 2018; Zhang et al., 2009).

In this current context, the aim of this review is to synthesise studies which are evaluating the cost of medicines used in the treatment of T2DM in the economically developed countries.

\section{Scope of the review}

We performed the cost analysis of medicines used in the treatment of T2DM in developed countries. PubMed, EMBASE, CINAHL, Cochrane Database of Systematic Reviews (CDSR) and Springer Link were reviewed for original articles. The reviewed papers considered T2DM from a health services or society perspective. The electronic search strategy included keywords such as, pharmaceuticals (e.g. "cost", “costs", “expenditure”), medicines (e.g. "drug” "drugs", "glucose lowering drugs", "medications", "medicine" or "medicines"), diabetes (e.g. "Type 2 diabetes", "Type 2 diabetes mellitus" or "hypoglycaemia") and economics (e.g. "direct cost", "hospitalization", "service cost", "cost of illness" or "health care cost"). The same keywords and search combinations were used in all databases. Included articles were published between 2007 to 2017. The included articles were written in the English language and required full-text to be available.

The review was limited to studies that evaluate the direct cost of T2DM and cost of medicines. Studies evaluating on policy changes of cost of medicines were left out. Further, we excluded studies that (i) did not distinguish between type 1 diabetes mellitus (T1DM) and T2DM, (ii) reported on cost of complication and comorbidities related to T2DM, (iii) did not assess 
relevant outcomes, and (iv) did not report on original data. The exclusion criteria are available in Table 1.

Table 1 Exclusion criteria

\section{Exclusion criteria}

- Studies that does not quote costs in results section

- Studies on adherence

- Studies on the saving on using one drug class instead of other

- Studies on comorbidities e.g. chronic kidney disease, heart conditions, obesity/lifestyle interventions

- Studies that do not differentiate between T1 and T2DM

- Studies that consider diabetic complications e.g. diabetes foot, diabetic nephropathy

- Cost-effectiveness, cost-utility and cost minimisation studies

- Studies on developing countries

- Conference abstracts, reviews, book etc.

- Diabetes with other co-morbidities (e.g. heart condition)

- Pharmacodynamics and pharmacokinetic studies

- Animal and in vitro studies

Relevant data regarding study population and study characteristics were extracted from the original data chosen. The standardised protocol and reporting form was adopted from PRISMA guidelines (Liberati et al., 2009) (appendix 1). Information on study design (e.g. cohort, crosssectional, bottom up approach), sample size (number of patients diagnosed with T2DM), data source (e.g. medical charts, interviews and questionnaires) and inclusion criteria (e.g. diagnosis codes used) are presented in table 2.

Table 2 Characteristics of included studies

\begin{tabular}{|c|c|c|c|c|c|c|c|c|c|}
\hline Country & $\begin{array}{l}\text { Setting for study } \\
\text { recruitment }\end{array}$ & Study design & Methods & $\begin{array}{l}\text { Study } \\
\text { duration } \\
\text { (year) }\end{array}$ & $\begin{array}{l}\text { Sample } \\
\text { size } \\
\text { (n) }\end{array}$ & Funding body & Inclusion criteria & $\begin{array}{c}\text { Mean } \\
\text { age } \\
\text { (years) }\end{array}$ & $\begin{array}{l}\text { Males } \\
(\%)\end{array}$ \\
\hline $\begin{array}{c}\text { Brazil } \\
\text { (Bahia et al., 2011) }\end{array}$ & $\begin{array}{l}\text { Primary, secondary and } \\
\text { tertiary care units }\end{array}$ & Retrospective study & $\begin{array}{l}\text { Questionnaire/ interviews } \\
\text { and Medical records }\end{array}$ & 2007 & 1000 & $\begin{array}{l}\text { Publicly } \\
\text { financed }\end{array}$ & $\begin{array}{l}\text { Diagnosed T2DM, no further } \\
\text { specification }\end{array}$ & 59 & 33.5 \\
\hline $\begin{array}{c}\text { Brazil } \\
\text { (Borges, Ferraz, \& } \\
\text { Chacra, 2014) }\end{array}$ & $\begin{array}{l}\text { Diabetes care centre, } \\
\text { tertiary care }\end{array}$ & Retrospective study & $\begin{array}{l}\text { Interviews and reviews of } \\
\text { medical charts, and } \\
\text { questionnaires }\end{array}$ & $\begin{array}{l}2009- \\
2010\end{array}$ & 209 & $\begin{array}{l}\text { Publicly } \\
\text { financed }\end{array}$ & $\begin{array}{l}\text { T2DM patients over } 18 \text { and having } \\
\text { regular follow-up consultations }\end{array}$ & 63 & 42 \\
\hline $\begin{array}{c}\text { Nothern Italy } \\
\text { (Demurtas et al., 2017) }\end{array}$ & Tertiary sector & Retrospective study & Medical records & 2012 & 24.087 & $\begin{array}{l}\text { Publicly } \\
\text { financed }\end{array}$ & $\begin{array}{l}\text { Diabetes classified as "insulin } \\
\text { treated diabetes", and "non-insulin } \\
\text { treated diabetes" above } 45 \text { years }\end{array}$ & 69.2 & 52 \\
\hline $\begin{array}{c}\text { Lithuana } \\
\text { (Domeikiene, Vaivadaite, } \\
\text { Ivanauskiene, \& Padaiga, } \\
\text { 2014) } \\
\end{array}$ & $\begin{array}{c}\text { Secondary care, } \\
\text { ambulatory and } \\
\text { hospital inpatient care }\end{array}$ & Top down approach & Medical records & 2011 & 762 & $\begin{array}{l}\text { Publicly } \\
\text { financed }\end{array}$ & $\begin{array}{l}\text { T2DM, ICD-10 diagnosis codes } \\
\text { E11.0-9 }\end{array}$ & 67.07 & 37.7 \\
\hline $\begin{array}{c}\text { Agentina } \\
\text { (Elgart et al., 2014) }\end{array}$ & $\begin{array}{l}\text { Secondary care, } \\
\text { hospital care }\end{array}$ & $\begin{array}{l}\text { Observational } \\
\text { retrospective study }\end{array}$ & $\begin{array}{l}\text { telephone interviews and } \\
\text { medical records }\end{array}$ & 2011 & 387 & $\begin{array}{l}\text { Publicly and } \\
\text { privately } \\
\text { financed }\end{array}$ & T2DM, ICD-10 & 63 & 45 \\
\hline $\begin{array}{c}\text { Germany } \\
\text { (Jacob, von Vultee, \& } \\
\text { Kostev, 2017) }\end{array}$ & $\begin{array}{l}\text { General practices and } \\
\text { diabetic centres }\end{array}$ & Retrospective study & Medical records & 2015 & 36382 & $\begin{array}{l}\text { Publicly and } \\
\text { privately } \\
\text { financed }\end{array}$ & Diagnosed T2DM & N/A & 52.2 \\
\hline $\begin{array}{c}\text { Spain } \\
\text { (Mata-Cases et al., 2016) }\end{array}$ & Primary care & Retrospective study & Medical records & 2011 & 126811 & $\begin{array}{l}\text { Publicly } \\
\text { financed }\end{array}$ & $\begin{array}{l}\text { T2DM, ICD-10 diagnosis codes E11, } \\
\text { E14 }\end{array}$ & 67.5 & 53.5 \\
\hline $\begin{array}{c}\text { Singapore } \\
\text { (Shuyu Ng, Toh, Ko, \& } \\
\text { Yu-Chia Lee, 2015) }\end{array}$ & Hospital and clinic & $\begin{array}{l}\text { Buttom up approach/ } \\
\text { cross-sectional study }\end{array}$ & & 2010 & 500 & $\begin{array}{l}\text { Publicly } \\
\text { financed }\end{array}$ & T2DM, ICD-9 code of 250 & 69 & 44.6 \\
\hline $\begin{array}{l}\text { Germany } \\
\text { (Ulrich et al., 2016) }\end{array}$ & Generel practitioner & Retrospective study & Questionnaires & $\begin{array}{l}2004- \\
2012\end{array}$ & 6803 & $\begin{array}{l}\text { Publicly and } \\
\text { privately } \\
\text { financed } \\
\end{array}$ & $\begin{array}{l}\text { Diagnosed T2DM, no further } \\
\text { specification }\end{array}$ & 71 & 54.1 \\
\hline
\end{tabular}


The findings were categorized into: i) mean annual direct cost, (ii) mean annual antidiabetic medicine cost, (iii) components included in the estimation for direct cost, and (iv) antidiabetic medicines included medicine cost (where possible cost of medicines for other conditions than diabetes has been excluded). When cost was expressed in other values than mean annual cost, these were calculated based on the published findings. The currency used for costs was calculated to express the corresponding 2017 values for US dollars. A 2 percent inflation rate has been used for these calculation (Barua, 2017). The exchange rate adopted in this study was $1 \mathrm{USD}=1.998$ and $1 \mathrm{USD}=0.0537 \mathrm{AR} \$$, which was the average exchange rate reported on December $31^{\text {st }} 2017$ (Yahoo, 2018). Where cost for both private and public tariffs were available it was preferred to use (i) average costs (ii) public tariff.

Quality of the studies was assessed by using a methodological quality appraisal tool. The tool is adapted from previous systematic reviews of quantitative studies (Louw, Morris, \& Grimmer-Somers, 2007; Roman, 2013; Wong, Cheung, \& Hart, 2008). A study score was calculated to rate the quality of studies. A study was scored 0 (no/not reported) or 1 (yes) for each study domain. The studies were judged on quality assessment items (e.g. response rate and applied tool) and relevance to current review (e.g. outcome measurements and study questions). The quality rating of each item was evaluated on a "poor", "fair" and "good" basis. Studies that scored from 0\%-33.9\% were considered weak, 34\%-66.9\% were considered moderate, and 67\%-100\% were interpreted as strong (Table 3).

The examples of cost calculations are provided below:

Example 1: Calculation of future value when currency is reported in US dollars:

$C=(1+r)^{n}$

, where $C$ = future value, $r=$ inflation $(2 \%)$, and $n=$ number of years since 2017

Brazil future value: $1,335 \$ *(1+0.02)^{12}=1,718.47 \$ \sim 1720 \$$

Example 2: Calculation of future value when reported currency is different from US dollars:

$C=(1+r)^{n}$

, where $C=$ future value, $r=$ inflation $(2 \%)$, and $n=$ number of years since 2017

Northern Italy future value $=3,312 € *(1+0.02)^{7}=3,803.89 € \sim 3,800 €$ 
Euros are now converted to US dollars. Exchange rate for last day of the year (31/12/2017) has been found to be 1.998 .

Mean value expressed in 2017 dollars: $3803.89 € * 1.998=7,600.18 \$$

Table 3 Quality appraisal tool a,b (Louw et al., 2007; Roman, 2013; Wong et al., 2008)

\begin{tabular}{|c|c|c|c|c|c|c|c|c|c|}
\hline Study & \multicolumn{5}{|c|}{ Quality assessment items } & \multicolumn{4}{|c|}{$\frac{\text { Relevance to current }}{\text { review }}$} \\
\hline & A & B & C & D & $\mathbf{E}$ & $\mathbf{F}$ & G & $\mathbf{H}$ & Score \% \\
\hline (Bahia et al., 2011) & 1 & 1 & 1 & 1 & 1 & 1 & 1 & 1 & $100 \%$ \\
\hline (Borges, Ferraz, \& Chacra, 2014) & 1 & 1 & 1 & 1 & 1 & 1 & 1 & 1 & $100 \%$ \\
\hline (Demurtas et al., 2017) & 1 & 1 & 1 & 1 & 1 & 1 & 1 & 1 & $100 \%$ \\
\hline $\begin{array}{l}\text { (Domeikiene, Vaivadaite, } \\
\text { Ivanauskiene, \& Padaiga, 2014) }\end{array}$ & 1 & 1 & 1 & 1 & 1 & 1 & 1 & 1 & $100 \%$ \\
\hline (Elgart et al., 2014) & 1 & 1 & 1 & 1 & 1 & 1 & 1 & 1 & $100 \%$ \\
\hline (Jacob, von Vultee, \& Kostev, 2017) & 1 & 1 & 1 & 1 & 1 & 0 & 1 & 1 & $87.5 \%$ \\
\hline (Mata-Cases et al., 2016) & 1 & 1 & 1 & 1 & 1 & 1 & 1 & 1 & $100 \%$ \\
\hline $\begin{array}{l}\text { (Shuyu Ng, Toh, Ko, \& Yu-Chia Lee, } \\
\text { 2015) }\end{array}$ & 1 & 1 & 1 & 1 & 1 & 1 & 1 & 1 & $100 \%$ \\
\hline (Ulrich et al., 2016) & 1 & 1 & 1 & 1 & 1 & 1 & 1 & 1 & $100 \%$ \\
\hline \multicolumn{10}{|c|}{$\begin{array}{l}\text { Abbreviations: } 0 \text { - No/not reported; } 1 \text { - Yes; A - Was the sample likely to be representative of the } \\
\text { study population?; B - Was a response rate mentioned within the study?; C - Was the instrument } \\
\text { used reliable?; D - Was the instrument used valid? E - Was it a primary data source? F - Does } \\
\text { study evaluate on direct cost used to treat TD2M?; G - Does study evaluate on cost of medicines } \\
\text { used to treat TD2M?; H - Does the patient have unambiguous diagnosis of T2DM? }\end{array}$} \\
\hline
\end{tabular}

\section{Characteristics of the study populations}

Our search identified 625 unique studies of which thirty-four were found eligible for full-text screening (figure 1). Nine of these studies (Bahia et al., 2011; Borges, Ferraz, \& Chacra, 2014; Demurtas et al., 2017; Domeikiene, Vaivadaite, Ivanauskiene, \& Padaiga, 2014; Elgart et al., 2014; Jacob, von Vultee, \& Kostev, 2017; Mata-Cases et al., 2016; Shuyu Ng, Toh, Ko, \& YuChia Lee, 2015; Ulrich et al., 2016) met our inclusion criteria. From the included original articles two studies are conducted in Brazil (Bahia et al., 2011; Borges et al., 2014) and Germany (Jacob et al., 2017; Ulrich et al., 2016) respectively, and one in Northern Italy (Demurtas et al., 2017), Lithuania (Domeikiene et al., 2014), Argentina (Elgart et al., 2014), Spain (Mata-Cases et al., 2016) and Singapore (Shuyu Ng et al., 2015). All nine studies, which 
were included in this article, have data on direct cost and antidiabetic medicine cost of health care.

Participants for the selected studies are recruited from across the healthcare sector; primary care, secondary care, and tertiary care. All patients were identified to have T2DM and they met the requirement defined in the respective studies (table 1). The mean age for people in the studies ranged between 59 and 71 . On average there were fewer number of males in the studies.

The studies used different definitions of T2DM as inclusion criteria (table 2). Four studies (Bahia et al., 2011; Borges et al., 2014; Jacob et al., 2017; Ulrich et al., 2016) identified the patients to have T2DM without further specification. One study (Demurtas et al., 2017) differentiated between T1DM and T2DM by categorising their medication as "insulin treated diabetes" and "non- insulin treated diabetes". Four studies (Domeikiene et al., 2014; Elgart et al., 2014; Mata-Cases et al., 2016; Ulrich et al., 2016) used ICD-9/ICD-10 codes to identify T2DM patients.

The estimation of the direct cost has different components and these components varied among the studies. Included components are for example medications, diagnostic tests, hospitalization, laboratory tests (table 4). Similarly, the medicines considered in the calculation of cost of medicines varied in the reviewed studies (table 4). The included medication can be categorized as (i) diabetes and obesity, (ii) antidiabetics/ glucose lowering drugs, (iii) no explanation of which medicines were included.

\section{Medical cost associated with diabetes}

All the included studies were assessed to score "strong" on the quality appraisal tool (table 3). Table 4, summarizes the distribution of the direct cost of T2DM, and the cost of diabetes mellitus medicines in the included studies. Six studies (Bahia et al., 2011; Borges et al., 2014; Demurtas et al., 2017; Domeikiene et al., 2014; Jacob et al., 2017; Shuyu Ng et al., 2015) define medications as "antidiabetics". Three studies (Elgart et al., 2014; Mata-Cases et al., 2016; Ulrich et al., 2016) defines medicines as “medicines used to treat T2DM". Currencies and price year used in the included studies have all been converted to US dollars using exchange rates for December $31^{\text {st }} 2017$. Currencies, price year and examples of calculation provided in the original studies can be found in appendix 2. 
Table 1 Cost of mean annual direct cost per person and mean annual medicine cost per person in the included studies.

\begin{tabular}{|c|c|c|c|c|c|c|c|c|c|}
\hline Country & $\begin{array}{l}\text { Price } \\
\text { year }\end{array}$ & $\begin{array}{l}\text { Currency/ } \\
\text { exchange } \\
\text { rate }\end{array}$ & $\begin{array}{l}\text { Income group } \\
\text { classification }\end{array}$ & $\begin{array}{l}\text { Direct cost estimated on } \\
\text { basis of following } \\
\text { components }\end{array}$ & $\begin{array}{l}\text { Mean } \\
\text { annual } \\
\text { direct } \\
\text { cost per } \\
\text { person }\end{array}$ & $\begin{array}{l}\text { Mean annual } \\
\text { direct cost per } \\
\text { person } \\
\text { expressed in } \\
\text { US dollars } \\
2017^{1,2}\end{array}$ & Medication cost estimated on basis of & $\begin{array}{c}\text { Mean annual } \\
\text { antidiabetic } \\
\text { medicine cost } \\
\text { per person (\% of } \\
\text { total direct cost) }\end{array}$ & $\begin{array}{l}\text { Mean annual } \\
\text { medicine cost } \\
\text { per person } \\
\text { expressed in } \\
\text { US dollars } \\
2017^{1,2}\end{array}$ \\
\hline $\begin{array}{l}\text { Brazil } \\
\text { (Bahia et al., } \\
\text { 2011) }\end{array}$ & 2005 & $\begin{array}{c}1 \text { USD }= \\
1.4 \mathrm{R} \$\end{array}$ & $\begin{array}{l}\text { Upper middle } \\
\text { income }\end{array}$ & $\begin{array}{l}\text { Medications, } \\
\text { diagnostic tests, } \\
\text { procedures, medical } \\
\text { supplies (such as } \\
\text { blood glucose test strips), } \\
\text { visits with health } \\
\text { professionals (physicians, } \\
\text { nurses, nutritionists, } \\
\text { physical therapists, } \\
\text { dentists, and } \\
\text { psychologists), } \\
\text { and hospital costs for } \\
\text { emergency room visits } \\
\text { (including } \\
\text { provider fees only). }\end{array}$ & 1,360 & 1,720 & $\begin{array}{l}\text { Medications used were categorized into four } \\
\text { groups: diabetes and obesity, cardiovascular } \\
\text { and dyslipidemia, psychiatric, and others (all } \\
\text { other classes of medications). }\end{array}$ & $250(18.38 \%)$ & $320^{2}$ \\
\hline $\begin{array}{l}\text { Brazil } \\
\text { (Borges, Ferraz, } \\
\text { \& Chacra, 2014) }\end{array}$ & 2009 & $\$$ & $\begin{array}{l}\text { Upper middle } \\
\text { income }\end{array}$ & $\begin{array}{l}\text { Procedures, } \\
\text { hospitalizations, } \\
\text { consultations, strips and } \\
\text { tests/examinations and } \\
\text { medications. }\end{array}$ & 1,000 & 1190 & $\begin{array}{l}\text { Medications was subdivided into four } \\
\text { categories: antidiabetics, } \\
\text { hypocholesterolinemics antihypertensives and } \\
\text { others }\end{array}$ & $\begin{array}{c}440 \\
(11.17 \%)\end{array}$ & 490 \\
\hline $\begin{array}{l}\text { Nothern Italy } \\
\text { (Demurtas et al., } \\
\text { 2017) }\end{array}$ & 2012 & $€$ & High income & $\begin{array}{l}\text { Hospitalization, outpatient } \\
\text { care cost, medications } \\
\text { cost }\end{array}$ & 3.310 & 7,600 & $\begin{array}{l}\text { Medications included: (meglitinides, non- } \\
\text { sulfonylureas, sulfonylureas, thiazolidinediones, } \\
\text { other antihyperglycemic agents, long and short- } \\
\text { acting insulins) }\end{array}$ & $870(26.40 \%)$ & $1000^{2}$ \\
\hline $\begin{array}{l}\text { Lithuana } \\
\text { (Domeikiene, } \\
\text { Vaivadaite, } \\
\text { Ivanauskiene, \& } \\
\text { Padaiga, 2014) }\end{array}$ & 2011 & $\begin{array}{l}1 \text { EUR }= \\
3.45 \mathrm{LTL}\end{array}$ & High income & $\begin{array}{l}\text { Type of treatment, } \\
\text { diabetes-related chronic } \\
\text { complications } \\
\text { (microvascular and } \\
\text { macrovascular), } \\
\text { consultations of general } \\
\text { practitioners and } \\
\text { specialists, laboratory } \\
\text { tests, covered drugs and } \\
\text { diabetes } \\
\text { supplies, ambulatory } \\
\text { procedures, } \\
\text { hospitalization, nursing }\end{array}$ & 9560 & 2,150 & $\begin{array}{l}\text { Direct cost of drugs are subdivided into: } \\
\text { Antidiabetic medication , hypoglycemic } \\
\text { medication, Oral and non-insulin injectable } \\
\text { hypoglycemic medication, Oral hypoglycemic } \\
\text { medication and insulin, Insulin Diagnostics } \\
\text { strips and Other medication }\end{array}$ & 450 (44.91\%) & 500 \\
\hline
\end{tabular}




\begin{tabular}{|c|c|c|c|c|c|c|c|c|c|}
\hline & & & & $\begin{array}{l}\text { services, healthcare at } \\
\text { home costs }\end{array}$ & & & & & \\
\hline $\begin{array}{l}\text { Argentina } \\
\text { (Elgart et al., } \\
\text { 2014) }\end{array}$ & 2011 & AR\$ & High income & $\begin{array}{l}\text { Medications } \\
\text { (including out-of-pocket } \\
\text { payment for prescribed } \\
\text { drugs), laboratory tests } \\
\text { and procedures, } \\
\text { hospitalizations, medical } \\
\text { and other associated } \\
\text { health professional } \\
\text { outpatient } \\
\text { visits (consultations). }\end{array}$ & 3,670 & 220 & $\begin{array}{l}\text { Does not differ between oral medicines used to } \\
\text { treat T2DM w/o complications. }\end{array}$ & $\begin{array}{c}2,650^{3} \\
(72.33 \%)\end{array}$ & 2990 \\
\hline $\begin{array}{l}\text { Germany } \\
\text { (Jacob, von } \\
\text { Vultee, \& } \\
\text { Kostev, 2017) }\end{array}$ & 2015 & $€$ & High income & $\mathrm{N} / \mathrm{A}$ & $\mathrm{N} / \mathrm{A}$ & $\mathrm{N} / \mathrm{A}$ & $\begin{array}{l}\text { Nine different families of antihyperglycemic } \\
\text { therapy were included in the analysis. The } \\
\text { annual antihyperglycemic treatment cost per } \\
\text { patient was calculated based on pharmacy retail } \\
\text { prices. }\end{array}$ & $500^{4}$ & 520 \\
\hline $\begin{array}{l}\text { Spain } \\
\text { (Mata-Cases et } \\
\text { al., 2016) }\end{array}$ & 2011 & $€$ & High income & $\begin{array}{l}\text { Primary care visits } \\
\text { (differentiating between } \\
\text { doctor's or } \\
\text { nurse's visits, and } \\
\text { between place of visit, i.e., } \\
\text { in the office } \\
\text { or at home), } \\
\text { hospitalizations, referrals } \\
\text { to specialist care, } \\
\text { diagnostic tests, } \\
\text { medication, dialysis } \\
\text { treatment, and use of } \\
\text { self-monitoring test strips. }\end{array}$ & 3110 & 7,140 & $\begin{array}{l}\text { Does not differ between medicines used to treat } \\
\text { T2DM. The retail prices were based on the } \\
\text { pharmacy billing information. }\end{array}$ & $930(29.74 \%)$ & 1060 \\
\hline $\begin{array}{l}\text { Singapore } \\
\text { (Shuyu Ng, Toh, } \\
\text { Ko, \& Yu-Chia } \\
\text { Lee, 2015) }\end{array}$ & 2010 & $\begin{array}{c}1 \mathrm{USD}= \\
1.3 \mathrm{~S} \$\end{array}$ & High income & $\begin{array}{l}\text { Inpatient hospitalisation, } \\
\text { accident and emergency } \\
\text { (A\&E) and ambulatory } \\
\text { outpatient care (physician } \\
\text { visits, allied } \\
\text { health visits, laboratory } \\
\text { tests and medications) }\end{array}$ & 1,580 & 1,800 & $\begin{array}{l}\text { The cost of drugs other than antidiabetics were } \\
\text { not included. }\end{array}$ & $\begin{array}{c}120 \\
(7.97 \%)\end{array}$ & 140 \\
\hline $\begin{array}{l}\text { Germany } \\
\text { (Ulrich et al., } \\
\text { 2016) }\end{array}$ & 2011 & $€$ & High income & $\begin{array}{l}\text { Outpatient services, } \\
\text { hospital care, } \\
\text { rehabilitation and } \\
\text { medication }\end{array}$ & 3350 & 7,540 & $\begin{array}{l}\text { Does not differ between } \text { medicines used to treat } \\
\text { T2DM. Pharmaceutical expenditures were } \\
\text { calculated from information on name, } \\
\text { pharmaceutical identification number and } \\
\text { dosage of drug intake during the previous } 7 \\
\text { days. If pharmaceuticals were taken irregularly, } \\
\text { the intake per week was assumed by using the } \\
\text { defined daily dose (DDD). }\end{array}$ & $\begin{array}{c}960 \\
(28.64 \%)\end{array}$ & 1080 \\
\hline
\end{tabular}

Page $\mathbf{8}$ of $\mathbf{1 8}$ 
${ }^{1}$ Original values and calculations can be found in appendix 1

2 Examples of calculations have been provided in methods section

${ }^{3}$ Expressed during a 3-month period (90 days) in original paper

${ }^{4}$ Estimate for overall population 
Table 4 also shows the spending on mean annual direct costs person in Northern Italy $(\$ 7,600)$ (Demurtas et al., 2017), Spain $(\$ 7,140)$ (Mata-Cases et al., 2016) and Germany $(\$ 7,540)$ (Ulrich et al., 2016) are quite similar. The two studies conducted in Brazil report almost same direct cost respectively $\$ 1,720$ (Borges et al., 2014) and $\$ 1,190$ but varies in annual medicine cost which are reported to be $\$ 320$ (Bahia et al., 2011) and \$130 (Borges et al., 2014). Almost two-fold difference is found in the cost of DM medicine in the two studies conducted in Germany, \$1040 (Jacob et al., 2017) and \$2160 (Ulrich et al., 2016) respectively. The medicine cost varied from $8 \%$ to $72 \%$ of the mean annual direct cost per person. The lowest expenditures were reported in Singapore (Shuyu Ng et al., 2015) and highest expenditures were reported in Argentina (Elgart et al., 2014).

Regardless of the methodology used in the individual study the mean annual direct cost was found to make a remarkable percentage of the mean annual cost. In Singapore $\$ 1,580$ per person/year was estimated to be spent on direct cost. This is estimated to be higher than other Asian countries e.g. India (Tharkar, Devarajan, Kumpatla, \& Viswanathan, 2010) and China (Wang et al., 2009). The authors suggest this difference to be due to the fact that the findings in the two latter mentioned studies were reported without considering inflation.

Expenses related to direct cost increases as disease progresses, age of the patient as well as the number of complications related to the condition (Bahia et al., 2011; Demurtas et al., 2017). The Italian NHS is especially challenged with this as there is expected to be an increased percentage of elderly compared to past, and thus the burden on the Italian NHS will be increased (Demurtas et al., 2017). This is in accordance with previous findings in the CODE2 study which reported that the prevention of diabetic complication may lead to a reduction in the overall healthcare expenditures (Williams, Van Gaal, \& Lucioni, 2002). There is a general agreement in the literature that policies that enforce prevention of diabetes and its complication are necessary as well as an optimization of healthcare resource allocation (Al-Maskari, ElSadig, \& Nagelkerke, 2010; Bahia et al., 2011; Borges et al., 2014; Lee, 2011; Shuyu Ng et al., 2015). 
When looking at the cost components there are two trends; some countries have reported a low expenditure on medicines e.g. Northern Italy (20\%) (Demurtas et al., 2017), Spain (30\%) (Mata-Cases et al., 2016), Singapore (8\%) (Shuyu Ng et al., 2015) and Germany (29\%) (Ulrich et al., 2016). The CODE-2 study (Jonsson, 2002), which compares data from eight European countries, similarly reported a low expenditure on medicines $(7 \%)$ and a large direct cost on hospitalisation. Contrary the two studies conducted in Brazil shows a high expenditure on the medical component. In the first study conducted in Brazil (Bahia et al., 2011) the overall cost of medication was $48 \%$ versus $42 \%$ in (Borges et al., 2014). This is similar to previous findings in Colombia (47\%)(González, Walker, \& Einarson, 2009), Iran (46\%) (Javanbakht et al., 2011). We suggest that the difference in expenditure can be explained by two reasons. The first one is the number of generic prescriptions in these countries. A high rate of generic prescribing would lower the overall medicine cost. The second reason is the reimbursement cost of each medicine in the respective countries.

\section{Expert commentary}

Our review has shown an insight into the cost of antidiabetic medicines while treating T2DM across different countries. There are differences in cost components included in the estimation of direct cost, but the commonality is that all studies include the cost of medicines as a component. We find that the reported direct cost and cost of antidiabetic medicines can be compared keeping the methodological limitations T1DM in mind. These assumptions are similar to previous studies which emphasizes on the importance of considering methodological approach when comparing the cost of diabetes (ADA, 2008, 2013; Bolin, Gip, Mörk, \& Lindgren, 2009; Jonsson, 2002). It was observed that the direct cost of T2DM was the significant component of overall health care cost. As mentioned earlier, the economic burden of diabetes has increased with more than $50 \%$ in the past 10 years.

Although there is a consensus that the use of antidiabetic medicines has increased since the 1990's only one of the reviewed articles (Jacob et al., 2017) investigated prescription patterns. This study reported that the annual expenditure on medicines was lower for metformin or sulfonylurea as compared to other glucose lowering agents such as Dipeptidyl peptidase-4 (DPP-4), Glucagon-like peptide-1(GLP-1), Sodium glucose transporter-2 (SGLT2). We suggest that the annual expenditure depends on the use generics i.e. metformin for sulfonylurea are older drugs, hence there is a lower cost compared to the newer drugs which 
are still under patent. (Melander et al., 2006), conducted a study which investigated the cost of antidiabetic medicines in ten European countries and found large differences in the use of antidiabetic medicines between neighbouring countries. They explained this by differences in screening policies and management of T2DM e.g. true and detected prevalence of disease and therapeutic traditions.

In the reviewed articles there is insufficient consideration to the factors that motivate the physicians prescribing behaviour e.g. price of the prescribed medicine, shared decision-making with patient and other external factors such as national and international guidelines. We find that pricing considerations when choosing which medicine to prescribe may be inappropriate as this would mean that all medicines are equally effective in all patients, which is not the case. Informed by national and international treatment guidelines, physicians should choose the most appropriate therapy for each individual patient. Given that there is an increase in prevalence of diabetes and patients are being diagnosed at a younger age the challenges to health care are becoming more extensive. An understanding of the motivating factors for choosing medicines will help define the magnitude of the problem. It should also be mentioned that the reported estimates of medicine cost do not include the economic burden associated with lifestyle changes and bariatric surgery.

The treatment of patients suffering from T2DM needs to be optimised in various settings. Firstly, there is a need to investigate on drug utilization and the economic burden of the prescribed medicines. Secondly, the increased efforts on glucose-lowering therapies has had an impact on diagnosis and health outcomes of patients suffering from T2DM. Despite the increased efforts to get glycaemic control it is not clear the how use of antidiabetic medicines is being reflected in the overall expenditures. We suggest a more comprehensive understanding of how physicians make choices about how they treat patients with T2DM, as well as a better understanding of the use of generic medicines, the influence of the patients and international guidelines in current practice. Lastly, a consensus approach to components included in estimates of economic evaluations would allow for more realistic and comparable cost estimates across countries.

\section{Five-year view}

In recent years, the financial burden of treating patients for T2DM has been projected to continue to increase and thus it is crucial to understand how each component contributes to 
these costs. Although several approaches have been taken to improve clinical outcomes i.e. by introducing target glycaemic levels and treatment guidelines many patients are still poorly managed. It is crucial to understand the reason for hospitalisation among T2DM to reduce the need for emergency care. A focus on differences in cost between poorly controlled patients and controlled patients are required to fulfil this gap. Despite the guidelines on treatment for T2DM none of the reviewed studies report on how the health care system in their country impact the way the physicians prescribe medicines. We find that the high expenditure on medicines can be kept down by increasing the use of generic medicines when treating patients with T2DM. The newer medicines are still under patents and thus cost more to prescribe than older medicines. We wonder if the physicians' prescribing behaviour is motivated by the national prescribing guidelines or are if they are steered by how much the insurance companies are willing to pay? It is important to mention that as prevalence increases the cost of treating complications related to T2DM will grow if current treatment regimens are maintained. Notably, the cost related to treating patients with undiagnosed diabetes is still an underexplored area. A number of evaluations have been made regarding the cost of medicines but there is no specific approach for the methodological approach. A consensus approach on components included in the analysis is required to adequately allow comparison between studies.

To strengthen the quality of future cost evaluation there should be more focus on methods of data collection. Non-specific ICD-codes makes it challenging to compare studied, and hence often excluded due to doubt about the patient' diagnosis. Up to October 2016 non-specific ICD9 and ICD-10 codes were commonly used in clinical practice. The introduction of updated codes ICD-9 and ICD-10 codes which are more specific should allow more precise comparison between studies in future. Another challenge is the discussion on optimal glycaemic control. The UKPDS (King, Peacock, \& Donnelly, 1999) included young newly diagnosed patients who are more likely to be successful in obtaining glyceamic control compared to patients from the ACCORD study (Gerstein et al., 2008) who are older and less healthy.

\section{Limitation of methods}

This review reports on direct cost and antidiabetic medicine cost attributable to T2DM between 2007 and 2017. Limitations of this review included use of different methodologies and differences in healthcare systems across countries. We believe that it is important to address the complexity in the current cost-estimates used when reporting on cost of medicines as the 
included components varies between studies. The methodological differences are for instance found in the inclusion criteria (table 2) and in the number of components included in the estimation of direct cost and cost of medicines (table 4). Below we have raised some of the methodological differences between the studies:

The setting of the study varies between the included studies. (Bahia et al., 2011) found no differences between secondary and tertiary levels of care, but generally there was a higher expenditure than in primary care. (Borges et al., 2014) reports, that their findings may be biased as the study only is conducted in one diabetes care centre. Further, the direct cost may be underestimated as the government has kept the prices of National Health Care cost frozen for years. Thus, they suspect their findings does not reflect the actual annual cost of T2DM all over the country.

A study conducted in the U.S shows that the cost associated with T1DM is higher than the prevalence of the disease and thus it is found inappropriate to combine these two groups when estimating the cost of diabetes (Tao, Pietropaolo, Atkinson, Schatz, \& Taylor, 2010). An Italian study (Bruno et al., 2008) which includes patients with both T1DM and T2DM shows that the cost of medicines was respectively 7.7 and 2.5 times higher compared the control group without diabetes. Two studies (ADA, 2013, 2018) conducted in the U.S, which does not differ between T1DM and T2DM, showed the cost ratio to be 3 and 2.9. In contrast, two German studies (Koster, Huppertz, Hauner, \& Schubert, 2014; Koster, von Ferber, Ihle, Schubert, \& Hauner, 2006) showed that there was no difference in cost ratio was (cost ratio of 1.9) in both groups compared to the control group.

The reviewed studies used different definitions for when a patient has T2DM. (Elgart et al., 2014), identified patients between 20 and 75 years and a 2-year follow up at the hospital, and also had an ICD-10. (Jacob et al., 2017), included patients over 40 years diagnosed with T2DM using the ICD-10 classification in the year of study (2015). A third study (Ulrich et al., 2016) used data from the patient' general practitioner. In case no valid information was available, a self-reported diabetes status was used. In cases where onset of disease was after 40 years patients were assumed to have T2DM. Patient without information about their diabetes status were excluded from the study. (Mata-Cases et al., 2016) reported, that they excluded individuals who died during the study period. A study conducted in U.S in 2007 showed that mortality related cost of T2DM make more than $50 \%$ of the direct cost, and thus the cost of diabetes medication may be under presented (ADA, 2008). We believe that there is a lack 
differentiation between T1DM and T2DM in the literature. The use of definition "T2DM" and using "ICD-codes" should make it easy to identify if the patient has T1DM or T2DM but in reality, it is not as easy as it seems. T2DM patient who are initiated on insulin-treatment may reclassified into T1DM after insulin initiation.

\section{Key issues}

- As prevalence increases the cost of treating complications related to T2DM will grow if current treatment regimens are maintained. None of the studies reviewed in this paper consider the cost of treating patients with undiagnosed diabetes.

- Given the number of available medicines and treatment in achieving glyceamic control, it is crucial to understand the physicians' reasons for prescribing older and newer antidiabetic medicines.

- The financial burden of treating patients for T2DM is continuing to increase, and thus it is crucial to understand how each component contribute to these costs.

- From the reviewed studies we were not able to find any data about if physicians' consider price of medicine or the most cost-effective treatment when prescribing medicines to the patients. Also, the costs of patients treated with lifestyle changes and bariatric surgery are not being considered.

\section{Contributions}

SR contributed to the study concept, design, analysis, interpretation and drafting manuscript. P.T. contributed to the study concept and interpretation. and S.S. contributed to data interpretation and manuscript development. Z-U-D contributed to the study concept, design, analysis and interpretation, editing of the paper.

\section{Acknowledgments}

No potential conflict of interest relevant to this article were reported.

\section{Funding}

None. 


\section{Disclosure}

All figures and tables are original and have not previously been published.

\section{Data sharing}

Available data can be obtained by contacting the corresponding author.

\section{References}

ADA. (2008). American Diabetes Association. Economic costs of diabetes in the U.S. In 2007. Diabetes Care, 31(3), 596-615. doi:10.2337/dc08-9017

ADA. (2013). American Diabetes Association. Economic costs of diabetes in the U.S. in 2012. Diabetes Care, 36(4), 1033-1046. doi:10.2337/dc12-2625

ADA. (2018). American Diabetes Association. Economic Costs of Diabetes in the U.S. in 2017. Diabetes Care, 41(5), 917-928. doi:10.2337/dci18-0007

\section{** A signiicant study on cost of diabetes in the U.S including both typ1 and typ2 diabetes patients.}

Al-Maskari, F., El-Sadig, M., \& Nagelkerke, N. (2010). Assessment of the direct medical costs of diabetes mellitus and its complications in the United Arab Emirates. BMC Public Health, 10, 679. doi:10.1186/1471-2458-10-679

Babar, Z. U., Grover, P., Stewart, J., Hogg, M., Short, L., Seo, H. G., \& Rew, A. (2011). Evaluating pharmacists' views, knowledge, and perception regarding generic medicines in New Zealand. Res Social Adm Pharm, 7(3), 294-305. doi:10.1016/j.sapharm.2010.06.004

Bahia, L. R., Araujo, D. V., Schaan, B. D., Dib, S. A., Negrato, C. A., Leo, M. P. S., . . Franco, L. J. (2011). The costs of type 2 diabetes mellitus outpatient care in the Brazilian Public Health System. Value in Health, 14(5 SUPPL.), S137-S140. doi:10.1016/j.jval.2011.05.009

Barua, A. (2017). Global inflation: Not yet a worry for most policymakers. Retrieved from https://www2.deloitte.com/insights/us/en/economy/global-economic-outlook/2017/q2global-inflation-not-yet-a-worry-for-central-banks.html

Bolin, K., Gip, C., Mörk, A. C., \& Lindgren, B. (2009). Diabetes, healthcare cost and loss of productivity in Sweden 1987 and 2005-a register-based approach. Diabetic Medicine, 26(9), 928-934. doi:10.1111/j.1464-5491.2009.02786.x

Borges, N. B., Ferraz, M. B., \& Chacra, A. R. (2014). The cost of type 2 diabetes in Brazil: Evaluation of a diabetes care center in the city of São Paulo, Brazil. Diabetology and Metabolic Syndrome, 6(1). doi:10.1186/1758-5996-6-122

Bruno, G., Karaghiosoff, L., Merletti, F., Costa, G., De Maria, M., Panero, F., . . Gnavi, R. (2008). The impact of diabetes on prescription drug costs: the population-based Turin study. Diabetologia, 51(5), 795-801. doi:10.1007/s00125-008-0957-4

Demurtas, J., Alba, N., Rigon, G., Nesoti, M. V., Bovo, C., \& Vaona, A. (2017). Epidemiological trends and direct costs of diabetes in a Northern Italy area: 2012 health administrative records analysis LHT n. 20 Verona. Prim Care Diabetes, 11(6), 570-576. doi:10.1016/j.pcd.2017.06.001

Diabetes.co.uk. Type 2 Diabetes. Retrieved from https://www.diabetes.co.uk/type2-diabetes.html Domeikiene, A., Vaivadaite, J., Ivanauskiene, R., \& Padaiga, Z. (2014). Direct cost of patients with type 2 diabetes mellitus healthcare and its complications in Lithuania. Medicina (Kaunas), 50(1), 54-60. doi:10.1016/j.medici.2014.05.007 
Elgart, J. F., Asteazaran, S., De La Fuente, J. L., Camillucci, C., Brown, J. B., \& Gagliardino, J. J. (2014). Direct and indirect costs associated to type 2 diabetes and its complications measured in a social security institution of Argentina. Int J Public Health, 59(5), 851-857. doi:10.1007/s00038-014-0604-4

Gerstein, H. C., Miller, M. E., Byington, R. P., Goff, D. C., Jr., Bigger, J. T., Buse, J. B., . . Friedewald, W. T. (2008). Effects of intensive glucose lowering in type 2 diabetes. N Engl J Med, 358(24), 2545-2559. doi:10.1056/NEJMoa0802743

\section{*** A significant study on clinical outcomes, especially tight glycemic control.}

González, C. J., Walker, J. H., \& Einarson, T. R. (2009). Cost-of-illness study of type 2 diabetes mellitus in Colombia. Revista Panamericana de Salud Publica/Pan American Journal of Public Health, 26(1), 55-63.

Hsia, Y., Neubert, A. C., Rani, F., Viner, R. M., Hindmarsh, P. C., \& Wong, I. C. (2009). An increase in the prevalence of type 1 and 2 diabetes in children and adolescents: results from prescription data from a UK general practice database. Br J Clin Pharmacol, 67(2), 242-249. doi:10.1111/j.1365-2125.2008.03347.x

IDF. (2018). International Diabetes Federation diabetes Atlas - 8th edition Retrieved from http://www.diabetesatlas.org/

\section{*** A significant study on cost of Type 2 diabetes in eight European countries.}

Jacob, L., von Vultee, C., \& Kostev, K. (2017). Prescription Patterns and the Cost of Antihyperglycemic Drugs in Patients With Type 2 Diabetes Mellitus in Germany. J Diabetes Sci Technol, 11(1), 123-127. doi:10.1177/1932296816658746

Javanbakht, M., Baradaran, H. R., Mashayekhi, A., Haghdoost, A. A., Khamseh, M. E., Kharazmi, E., \& Sadeghi, A. (2011). Cost-of-illness analysis of type 2 diabetes mellitus in Iran. PLOS ONE, 6(10). doi:10.1371/journal.pone.0026864

Jonsson, B. (2002). Revealing the cost of Type II diabetes in Europe. Diabetologia, 45(7), S5-12. doi:10.1007/s00125-002-0858-x

King, P., Peacock, I., \& Donnelly, R. (1999). The UK Prospective Diabetes Study (UKPDS): clinical and therapeutic implications for type 2 diabetes. Br J Clin Pharmacol, 48(5), 643-648. doi:10.1046/j.1365-2125.1999.00092.x

\section{*** A significant study on clinical outcomes, especially glycemic control.}

Koster, I., Huppertz, E., Hauner, H., \& Schubert, I. (2014). Costs of Diabetes Mellitus (CoDiM) in Germany, direct per-capita costs of managing hyperglycaemia and diabetes complications in 2010 compared to 2001. Exp Clin Endocrinol Diabetes, 122(9), 510-516. doi:10.1055/s-00341375675

Koster, I., von Ferber, L., Ihle, P., Schubert, I., \& Hauner, H. (2006). The cost burden of diabetes mellitus: the evidence from Germany--the CoDiM study. Diabetologia, 49(7), 1498-1504. doi:10.1007/s00125-006-0277-5

Lee, K. W. (2011). Costs of diabetes mellitus in Korea. Diabetes Metab J, 35(6), 567-570. doi:10.4093/dmj.2011.35.6.567

Liberati, A., Altman, D. G., Tetzlaff, J., Mulrow, C., Gøtzsche, P. C., loannidis, J. P. A., . . Moher, D. (2009). The PRISMA statement for reporting systematic reviews and meta-analyses of studies that evaluate healthcare interventions: explanation and elaboration. Bmj, 339. doi:10.1136/bmj.b2700

Louw, Q. A., Morris, L. D., \& Grimmer-Somers, K. (2007). The prevalence of low back pain in Africa: a systematic review. BMC Musculoskelet Disord, 8, 105. doi:10.1186/1471-2474-8-105 
Mata-Cases, M., Casajuana, M., Franch-Nadal, J., Casellas, A., Castell, C., Vinagre, I., . . Bolibar, B. (2016). Direct medical costs attributable to type 2 diabetes mellitus: a population-based study in Catalonia, Spain. Eur J Health Econ, 17(8), 1001-1010. doi:10.1007/s10198-0150742-5

Melander, A., Folino-Gallo, P., Walley, T., Schwabe, U., Groop, P.-H., Klaukka, T., . . L Lindblad, U. (2006). Utilisation of antihyperglycaemic drugs in ten European countries: different developments and different levels. Diabetologia, 49(9), 2024-2029. doi:10.1007/s00125006-0331-3

Roman, N. F., JM. . (2013). The prevalence of intimate partner violence in the family: A systematic review of the implications for adolescents in Africa. . Family Practice, 30(3), 228-246.

Saito, I., Kokubo, Y., Yamagishi, K., Iso, H., Inoue, M., \& Tsugane, S. (2011). Diabetes and the risk of coronary heart disease in the general Japanese population: the Japan Public Health Centerbased prospective (JPHC) study. Atherosclerosis, 216(1), 187-191. doi:10.1016/j.atherosclerosis.2011.01.021

Shuyu Ng, C., Toh, M. P., Ko, Y., \& Yu-Chia Lee, J. (2015). Direct medical cost of type 2 diabetes in singapore. PLOS ONE, 1O(3), e0122795. doi:10.1371/journal.pone.0122795

Tao, B., Pietropaolo, M., Atkinson, M., Schatz, D., \& Taylor, D. (2010). Estimating the cost of type 1 diabetes in the U.S.: a propensity score matching method. PLoS ONE, 5(7), e11501. doi:10.1371/journal.pone.0011501

Tharkar, S., Devarajan, A., Kumpatla, S., \& Viswanathan, V. (2010). The socioeconomics of diabetes from a developing country: a population based cost of illness study. Diabetes Res Clin Pract, 89(3), 334-340. doi:10.1016/j.diabres.2010.05.009

Ulrich, S., Holle, R., Wacker, M., Stark, R., Icks, A., Thorand, B., . . Laxy, M. (2016). Cost burden of type 2 diabetes in Germany: results from the population-based KORA studies. BMJ Open, 6(11), e012527. doi:10.1136/bmjopen-2016-012527

Wang, W., McGreevey, W. P., Fu, C., Zhan, S., Luan, R., Chen, W., \& Xu, B. (2009). Type 2 diabetes mellitus in China: A preventable economic burden. American Journal of Managed Care, 15(9), 593-601.

Williams, R., Van Gaal, L., \& Lucioni, C. (2002). Assessing the impact of complications on the costs of Type II diabetes. Diabetologia, 45(7), S13-17. doi:10.1007/s00125-002-0859-9

Wong, W. C., Cheung, C. S., \& Hart, G. J. (2008). Development of a quality assessment tool for systematic reviews of observational studies (QATSO) of HIV prevalence in men having sex with men and associated risk behaviours. Emerg Themes Epidemiol, 5, 23. doi:10.1186/17427622-5-23

Yahoo. (2018, ). Yahoo Finance. Retrieved from https://uk.finance.yahoo.com/currency-converter/

Zhang, Y., Dall, T. M., Mann, S. E., Chen, Y., Martin, J., Moore, V., .. Quick, W. W. (2009). The economic costs of undiagnosed diabetes. Popul Health Manag, 12(2), 95-101.

** A significant study on the economic cost of undiagnosed diabetes 